fiscalía, y que no son más que una adaptación de los summary trials ingleses y galeses. En estos procesos, que representan el noventa por ciento de los casos judiciales, el acusado evita gastos al erario público mediante la declaración de culpabilidad, que puede realizarse incluso por carta, y de este modo recibe una sentencia rápida y por lo general atenuada.

Más allá de los límites del derecho, se trata ésta de una obra de utilidad para gran número de profesionales. Como filólogos, en primer lugar, no podemos sino agradecer la excelente visión comparativa del lenguaje jurídico en inglés y en español, respaldada por sólidas bases lingüísticas; del mismo modo, entendemos que los estudios sobre civilización inglesa, de reciente incorporación en los nuevos planes de estudio de filología, han de tener como parte fundamental el análisis de las instituciones del derecho inglés, que en gran medida determinan la ideosincrasia británica. Los sociolingüistas, por su parte, encontrarán apasionante la especialización de la jerga de los jueces y abogados, que convierte el código utilizado en una manifestación de poder, que deja inermes a los que no pueden utilizarla ni entenderla, y que sin duda alguna podría dar lugar a estudios paralelos sobre cómo se establecen idénticas relaciones en castellano.

Miguel Ángel Campos Pardillos

Janet A. Kourani, James P. Sterba and Rosemarie Tong, eds. Feminist Philosophies. New York and London: Harvester-Wheatsheaf, 1992, IX + 406 pp.

Feminism or Feminisms? It is a difficult and intriguing question. Some people-probably mainly women and men committed to the project of gender equality - would answer feminisms. Not one but many. Other people, maybe less informed, would consider the question as uninteresting and answer vaguely: feminism. Just one. But what do we really mean when we speak or write on women and feminism? What do we mean when we question the construction of the normative feminine identity? Is it anachronistic to go on discussing these topics? Shall we have to yield to the temptation of falling into the trap of the theorists that have claimed the death of feminism and that have foreshadowed the arrival of the era of postfeminism?

Obviously, Feminist Philosophies does not contain the answers to these questions, but we think that it represents a useful and intelligent starting point to get closer to a better understanding of contemporary feminist theories. It can be a good, and extremely well structured, introduction to the expanding field of gender studies for all the people that have not had the chance to approach the subject or want to know more about it. At the same time, it is a good antology of some of the best essays written on the philosophy of feminism to keep at hand. In short, as the editor points out in the preface: "This antology is designed to be a basic course in feminist philosophy or a first course in women's studies" (ix).

The book is composed of a collection of 40 essays; it is divided into two parts, a Methodological Postscript and a bibliographical section with suggestions for further reading. Part I is divided into seven sections: Sex-Role Socialization, Sexuality, 
Reproduction, Self-Images, The World of Work, The Domestic Scene and Cultural Invisibility. The second part is composed of five sections: Liberal Feminism, Radical Feminism, Psychoanalitic Feminism, Marxist/Socialist Feminism and Postmodern Feminism. The contents of the book and its structure underline two main ideas. The first is to relate women as social subjects to our contemporary reality and the second is to present the main theoretical schools within the field of gender studies.

The normative sexual identity, the family, the work place or the construction of the feminine body are parts of the mosaic that make up the life of most women. The assigned essentialist identity that women have to suffer and all the problems related to the construction of this identity, materialize in a number of rules that they are expected to obey and accept in order to be considered as feminine. The dominant ontological discourse that construe the feminine normative self acts through a network of power relations that are located in multiple sites. Sexuality is one of these sites and, within this field, the control over reproduction - or the free access of women to legal abortion, for instance-is an argument that is strictly related to the question of women's right and to the right that every individual has to maintain control over his or her sexuality. This means that to lose control over one's sexuality is equal to losing power over an important part of your life.

Other prominent fields where power relations act powerfully are the work place -difference in wages and benefits, for example-or the "disciplinary practices" that many women undergo to shape their bodies according to a discourse that, depending on fashion or other historical and cultural factors, wants them different all the time. As Sandra Bartky points out in an essay included in this collection:

Styles of the female figure vary over time and across cultures: they reflect cultural obsessions and proccupations in ways that are still poorly understood. Today, massiveness, power, or abundance in a woman's body is met with distaste ... It is a silhouette that seems more appropriate to an adolescent boy or a newly pubescent girl than to an adult woman. Since ordinary women have normally quite different dimensions, they must of course diet. (105)

Literary history is another field where the contribution made by women along the centuries has very rarely been considered as important or relevant. But, according to the French philosopher Michel Foucault, within the relation power/knowledge writing can be considered as a mode of resistance and it is in this sense that some feminist theorists are committed to rediscovering and publishing works written by women and try to remedy the "cultural invisibility" that these texts-novels, poems, essays, short stories, etc.-had been condemned to in the last centuries.

As we have stressed before, the section Cultural Invisibility is the last of Part I and it acts as a bridge between the first and the second part of Feminist Philosophies. If the essays of Annette Kolodny, Joan Scott, Rosemary Radford Ruether and Sue Rosser stress the enormous importance that the feminine voice and the feminist perspective have in the cultural and religious field, in Part II of the book their call materializes in a number of essays that introduce the reader to a variety of feminist theories.

At the beginning of this review we were wondering if it is possible to talk of feminism as a unique and unitary concept or if, on the contrary, we have to consider feminism as a 
multiplicity where different points of views melt and if what they have in common is a political and social commitment not only to gender equality, but to the elimination a a politics of exclusion based on gender, race, social class or sexual orientation. We personally think that it is not possible, nowadays, to talk of just one feminism and the essays published in the second part of Feminist Philosphies sustain this point of view. They represent the variety of perspectives and the wide range of social and philosophical tendencies that exist within the field of gender studies. From the liberal feminists' ideas to the postmodern theorists; approaching the marxist perspective or getting closer to the radical feminists' point of view, the reader is introduced, in an easy and skilled way, into the complex and lively theoretical world of feminist theories.

As we have pointed out above, a certain understanding of sexuality, reproduction or the construction of the feminine body, among other things, can represent a way to limit the active participation of women in the social, cultural and economical sphere. In this context we think that the questioning of the normative ontological and epistemological categories that feminist intellectuals, men and women, are carrying on is of basic importance for the development of a fairer politics of gender equality. Their work relates women as marginalized social individuals to theories that can suggest solutions to overcome the politics of gender discrimination that exclude a great part of the feminine population from an active social and political role. In this sense, we think that the editors of Feminist Philosophies have been able to offer a good and professional summary example of this intellectual project.

Silvia Caporale Bizzini

\section{Gregory Comnes. The Ethics of Indeterminacy in the Novels of William Gaddis. Gainesville: UP of Florida, 1994, $188 \mathrm{pp}$.}

The interrelation between ethic and aesthetic judgment remains a missing point in many theoretical and critical studies on contemporary fiction. Why postmodern fiction is or is not innovative from the formal point of view has been thoroughly explained by many scholars, and the myriad devices that sustain what is usually referred to as "self-conscious fiction" have been already classified; but the importance of avant-garde experiments to our comprehension of reality has not been, in my view, carefully examined.

Gregory Comnes's study is a brilliant effort to fill this gap in the particular context of Gaddis's fiction. But his recent book on Gaddis is both necessary and useful for another reason. Besides partially filling this gap existing in the field of studies on the postmodern novel, it also provides an example of the ethical relevance of fiction to our understanding. Like Coover or Pynchon, Gaddis is one of those contemporary authors for whom the consideration of "relativism" is, or should be, a basic assumption when it comes to organizing and evaluating reality. The dismantling of what Lyotard calls "grand narratives" is one of his chief concerns, as it is of many other contemporary novelists-the relevant question in Gaddis's fiction being that the problematization of our comprehension of reality takes on its important ethical dimensions as well. Implied, in Gaddis's fiction as 